\title{
Angioid streaks and traumatic ruptures of Bruch's membrane
}

\author{
A. HAGEDOORN \\ From the Department of Ophthalmology, Vrije Universiteit, Amsterdam, Holland
}

Duke-Elder (1972) referred to a paper of mine (Hagedoorn, 1950) as follows:

'It was suggested by Hagedoorn (1950) that traumatic ruptures of Bruch's membrane may occur. In case of a concussive injury, after a vitreous haemorrhage had cleared, haemorrhagic streaks were observed in the fundus along ruptures of this membrane, an observation which indicates that some cases of angioid streaks may be of traumatic origin.'

This misunderstanding, evidently due to publication in the Dutch language, should be corrected because of its scientific, clinical, and legal implications. In a clinical lecture (Hagedoorn, 1950) I emphasized the importance of an accurate examination even in minor blunt traumata of the eye with subjective complaints and mentioned among other patients the following case:

A young man presented in the out-patients department with a vitreous haemorrhage after a slight concussion. There were no other signs of trauma in the eye and a presumptive diagnosis of juvenile periphlebitis was made. The haemorrhage rapidly cleared; there were streaklike haemorrhages in the fundus but no evidence of periphlebitis. Examination of the other eye for periphlebitis was negative as was a general examination.

A grey homogeneous aspect of the central part of the fundus with a dotted transitional zone to a translucent Bruch's membrane in the periphery, where the choroidal vessels are clearly visible-as described by Zeeman (I933): 'Angioid streaks without angioid streaks'-is characteristic of a first stage of this clinical picture. In this case, however, even in the reproduction of the illustration (Figure I in the original paper), the well-known tiny lines and breaks of true angioid streaks may be traced.

The unusual shape of the retinal haemorrhages evidently had to be attributed to new breaks or enlargement of existing breaks which were due to the minor blunt trauma in an eye affected by the typical degeneration of Bruch's membrane, known as Address for reprints: Professor A. Hagedoorn, MD, as above. 'angioid streaks'. In the other eye, which showed the same central greyness and dots, tiny angioid streaks could also be traced. But at that time no pseudoxanthoma had developed, nor were there other signs of the disease (calcified vessels).

It is significant that a brother had suddenly died of gastric haemorrhage.

In our first patient, who was first presented at the Dutch Ophthalmological Society (Hagedoorn, I937a) and thereafter extensively published (Hagedoorn, I939), there were also severe degenerations in the elastic tissue of the blood vessels of the intestines. They were described by Sekir in a chapter of Prick's monograph on pontine bulbar paralysis by pseudoxanthoma elasticum (Prick, 1938). Sekir was killed in the bombing of Rotterdam, as I stated in my discussion with Verhoeff on the nature of angioid streaks (Hagedoorn, I939; Verhoeff, I939) in which I referred to his findings at necropsy, which I believe to be the first pathological description of this disease. My conclusion that angioid streaks may be caused by premature ageing of the elastic fibres (Hagedoorn, 1939) was supported by this discussion and recently by Hervouët ( 1962 ) in a comment on the paper of Levasseur (1962). Levasseur discussed trauma and angioid streaks, and referred to a paper of Streiff and Portmann (I95I) who suggested that claims for damages might be reduced if angioid streaks were present. Apart from more serious lesions, minor blunt trauma in a healthy young eye may lead to ruptures of the choroid and occasionally of the pigmented epithelium (Hagedoorn, r937b), but not to these streaklike haemorrhages or ruptures of Bruch's membrane as seen in angioid streaks.

\section{Summary}

Minor blunt trauma may cause typical haemorrhages and probably enlargement of breaks or new breaks in patients affected with the Groenblad-Strandberg syndrome.

\section{References}

DUKE-ELDER, S. (1972) 'System of Ophthalmology', vol. I4, pt I, p. I57. Kimpton, London HAGEdoorn, A. (I937a) Ned. T. Geneesk., 8r, 3003

\section{- (1937b) Amer. 7. Ophthal., 20, 13 (1939) Arch. Ophthal., 21, 746; 935 (1950) Ned. T. Geneesk., 94, 3620}

Levasseur, J-C. (I962) Bull. Soc. franf. Ophtal., 75, 530; disc (Hervouët, M. F., p. 54I)

PRICK, J. J. G. (I938) Pontine pseudobulbairparalyse by pseudoxanthoma elasticum. Gebr. van Aelst, Maastricht

(Sekir, P. E., p. 136; Hagedoorn, A., p. I4I)

STREIFF, F. H., and PORTMANN, U. P. (I95I) Ophthalmologica (Basel), r21, 87

VERHoeff, F. H. (1939) Arch. Ophthal., 22, 313 (Hagedoorn, A., p. 679)

zeEMan, w. P. c. (1933) Ned. T. Geneesk., 77, 1938 